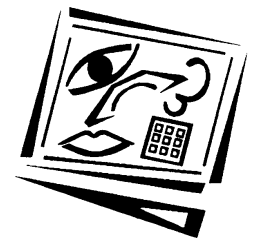

\title{
Online collaboration and offline interaction between students using asynchronous tools in blended learning
}

Mei-jung Wang

National Kaohsiung University of Hospitality and Tourism

\begin{abstract}
The increasing use of innovative blended learning strategies which incorporate online discussion into the classroom requires the examination of asynchronous, computer mediated communication (ACMC) to fully understand the learners' total engagement and the contribution of such ICT tools to student learning. This study analysed students' online utterances and offline interactions, to determine the extent of collaborative learning among students from two colleges. Results show that behaviours that characterise successful collaborative learning in an asynchronous networked environment were present, but the patterns were different from previous studies. The implementation of ICT tools in blended learning does promote social interaction among students and their engagement; however, it does not automatically facilitate students in their adoption of active learning strategies. The offline atmosphere in carrying out the ACMC activities were sorted into five major categories: struggling with platform operations, handling technical problems, passive attitudes towards the procedure, tense atmosphere in class, and engagement in tasks. Based on the findings, some pedagogical implications are presented.
\end{abstract}

\section{Introduction}

Given that language learning is facilitated when students use language to perform meaningful tasks based on practices that people do in the real world (Edwards \& Willis, 2005), pedagogical approaches to using computer assisted language learning (CALL) and information and communication technologies (ICT) are shifting to forms which better exploit the communication, collaboration, and negotiation aspects of the Internet (Curtis \& Lawson, 2001; Hoven, 2006; Meyer, 2004; Murphy, 2004). Learning on the Internet is highly compatible with social constructivism, which emphasises the manner in which learners actively construct their knowledge on the basis of what they already know through social interaction in learning contexts, rather than passively receive knowledge in a pre-packaged form (Self, Karakirik, Kor, Tedesco \& Dimitrova, 2000; Vygotsky, 1978). Research into CMC (computer mediated communication), for example, indicates the significant potential of text-based interaction within the sociocultural perspective (Kitade, 2008; Payne \& Ross, 2005). Studies of both SCMC (synchronous $\mathrm{CMC}$ ) and $\mathrm{ACMC}$ (asynchronous CMC) have investigated the extent to which online interaction with peers impact learners' language development (Belz, \& Kinginger, 2002; Berg, 1999; Pawan, Paulus, Yalcin \& Chang, 2003, Schellens \& Valcke, 2006; Warschauer, 2002).

However, most of the previous studies on computer conferencing systems in education focus mainly on asynchronous online discussion (Hrastinski, 2009). The increasing use of innovative blended learning strategies which incorporate online discussion into in 
class, face to face settings, and rapid developments in the use of ICT in higher education (An \& Frick, 2006; Chen \& Looi, 2007; Ginns \& Ellis, 2009; Ng \& Cheung, 2007) require the examination of ACMC in class activities to fully understand the learners' total engagement (Kitade, 2008) and the contribution of such ICT tools to student learning (Ginns \& Ellis, 2009; Hourigan \& Murray, 2010). To understand online collaborative characteristics and offline interaction among students from two different colleges in a blended learning environment, this study analysed students' online utterances to determine the extent of collaborative learning in online interaction. In addition, students' offline atmosphere in class was observed to reveal the possible impact of the implementation of in class online discussion upon in class activities. Finally, learners' perceptions of the value of such a blended ACMC learning activity for language learning were examined.

\section{Literature review}

Currently, many educators are focusing their efforts on the design and implementation of more active and collaborative methods of teaching and learning, in order to better prepare learners for the team work and project/problem solving approaches necessary for work places in the 21st century (Moisseeva, Steinbeck \& Seufert, 2007). Various kinds of $\mathrm{CMC}$, both synchronous and asynchronous, explore the interactive dimensions of such text-based interactions within a Vygotskian sociocultural perspective, and suggest that CMC facilitates learner-centred communication, promotes critical thinking, enhances knowledge construction, and creates collaborative learning communities (Felix, 2002; Ferdig \& Trammel, 2004; Levy \& Kennedy, 2004; Loewen \& Erlam, 2006).

Asynchronous $\mathrm{CMC}$ (ACMC) enables language learners to engage in interactions with a wider range of interlocutors because ACMC is not bounded by the limits of time or space (Hanson-Smith, 1997; Kitade, 2008). This facilitates participation among students because it allows all students an equal opportunity to respond to a topic (Birch \& Volkov, 2007; Branon \& Essex, 2001; Ortega, 1997), and is also conducive to the presentation of heterogeneous perspectives (Chen \& Looi, 2007; Moisseeva, Steinbeck, \& Seufert, 2007). Consequently students learn to express themselves, are exposed to alternative points of view, and are better positioned to respect differences in opinions, since none of the participants can easily dominate the discussion (Branon \& Essex, 2001; Ortega, 1997). Furthermore, the asynchronous features also provide learners with more time to think and edit. Students involved in online discussions create more thoughtful responses because they have more time to process input (Abrams, 2003) and to reflect on what they want to express (Althaus, 1996).

Learner-centred online discussion forums can facilitate learners' construction of knowledge through collaboration in groups by providing the requisite environment for the social negotiation of meaning ( $\mathrm{Ng} \&$ Cheung, 2007; Romiszowski \& Mason, 2004). Students who use English as a second language or a foreign language tend to have less experience of critically engaging in the course content in face to face discussion probably because it is 'face threatening' (Birch \& Volkov, 2007; Chen \& Looi, 2007; Liu \& Jackson, 2008). Chun (1994) found that students who were involved in $\mathrm{CMC}$ produce more language through questioning, clarifying, and feedback giving than in traditional classrooms. Chen and Looi (2007) also indicated that online discussion contains more opportunities for the practice of in depth clarification and 
inferencing skills. By engaging learners in deeper language processing, $\mathrm{CMC}$ has great potential to increase the quality and quantity of learner output.

The amount and quality of interaction among participants is widely acknowledged to be an indicator of successful online learning experiences, as interaction has been found to contribute to both achievement and student satisfaction (Guzdial \& Turns, 2000; Roblyer \& Wiencke, 2004). Interaction among course participants helps them apply and integrate newly gained knowledge in the course of engaging in group activity. A range of behaviours that characterise successful collaborative learning in an asynchronous networked environment, including on task activities, social chat, mutual explanations, and other regulatory behaviours, have been identified in Curtis and Lawson's (2001) study. However, few researchers explore how the interactions in class influence online interaction. Kitade (2008) suggests that studies on ACMC should address the role of offline interactions, or the learners' engagement in combined online and offline interactions, to gain a more complete understanding of how learners actually benefit from carrying out CMC tasks.

The approach of combining face to face instruction with computer mediated instruction is called blended learning (Bonk \& Graham, 2005), which has been adopted by many educators in higher education (An \& Frick, 2006; Chen \& Looi, 2007; Ng \& Cheung, 2007). As an alternative to traditional face to face instruction and CMC activities, blended learning represents an attempt to amplify the strengths of each environment while at the same time minimising their weaknesses. For example, the lack of rich communication seems to affect the time taken to complete communications or tasks in CMC (An \& Frick, 2006) but students were linguistically more creative and sophisticated during CMC (Blake, 2005; Kern, 1995; Warschauer, 2002). DeSanctis and Monge (1998) claimed that CMC is more effective than face to face communication for divergent tasks such as idea generation, while face to face communication is more effective for convergent tasks, such as decision making, which require interdependence on others. Chen and Looi (2007) and Ng and Cheung (2007) pointed out that integrating online discussion into the flow of the instruction in the classroom provided learners with ample time to foster habits of critical thinking, reflection, and articulation of their viewpoints, which can subsequently promote further in class oral discussions or outside class online discussions.

The quality of interaction is of equal importance in both face to face and online environment. Ginns and Ellis (2009) emphasise that blended learning experience provides a mix of both online and face to face experiences, which support each other in achieving desired learning outcomes. Thus evaluating the quality of blended learning requires relating the 'part' of the online learning context, such as online activities and discussions, to the 'whole' of the student experience including the totality of both online and face to face learning experiences. In light of the literature reviewed, this study investigated collaborative communication among students from two different colleges in an ACMC environment. Specifically, this study sought to examine the subjects' collaborative characteristics among online interlocutors and their interaction with offline peers. The research questions addressed in this study are as follows:

1. What are the online collaborative characteristics of the two groups of students?

2. What are the offline interactions of the two groups in their own classes? 


\section{Method}

\section{Participants}

Two groups of subjects from Applied English Departments, 25 students from a college in southern Taiwan (College A hereafter) and 50 students from a college in central Taiwan (College B), participated in this study. Their English proficiency is about intermediate level (about TOEIC 550). All of the participants were first year students and had experiences using $\mathrm{CMC}$, such as email and chat room. They took part in the study as part of their regular English class. The students' class met for two hours each week. The first four weeks of their courses were used to collect data for the present study. Students were grouped into 12 groups for the project. Each of the discussion groups consisted of a random selection of two students from college A and four students from College B. During the data collection process, they accomplished the reading and discussion tasks under the guidance of the same instructor.

\section{Tasks and procedure}

The participants were involved in this project for a total of four weeks. During the first week, an instructional manual informing the participants about the study and platform was distributed. The instructor also gave an orientation about how the project was implemented to make sure that the participants understood the whole process. The Ubiquitous Hospitality English Learning Platform (U-HELP) (Wang, 2009) was used in this study. Students first read three hospitality featured articles (Welcome to Taiwan: Hotel Accommodation; the Top 10 Taiwan Destinations among Foreign Tourists, and Night Market Snacks) on the U-HELP (Figure 1). Afterwards, they discussed the questions provided by the instructor on the discussion board (Figure 2) with their group mates (a requirement) or with other groups (an option). The procedure for the online reading and discussion activities was as follows:

1. They read three reading selections located under Teachers' Portfolio/ Reading Club.

2. Whenever students finished one reading selection, they wrote down the main ideas and summary on the Interaction/ Discussion Board.

3. Students were required to answer the three discussion questions relevant to the three reading selections in the group blogs after class.

4. Each group had a chairperson who was responsible for posting the first message after finishing each reading article.

5. In the discussion process, each group could continue the same topic until every Friday, and the Chair drew a conclusion. Every member was required to reply to other group members' postings at least twice a week.

6. Each group needed to reply to another group's discussion content at least once every week.

7. They were encouraged to give feedback to any other group's blog.

8. During the discussion process, all forms of instant online messenger services (e.g. MSN, Yahoo Messenger, or Skype) were not allowed. They could only use U-HELP blogs to communicate with each other. When they finished the three articles, they filled in a post-reading activity questionnaire and wrote a report. 


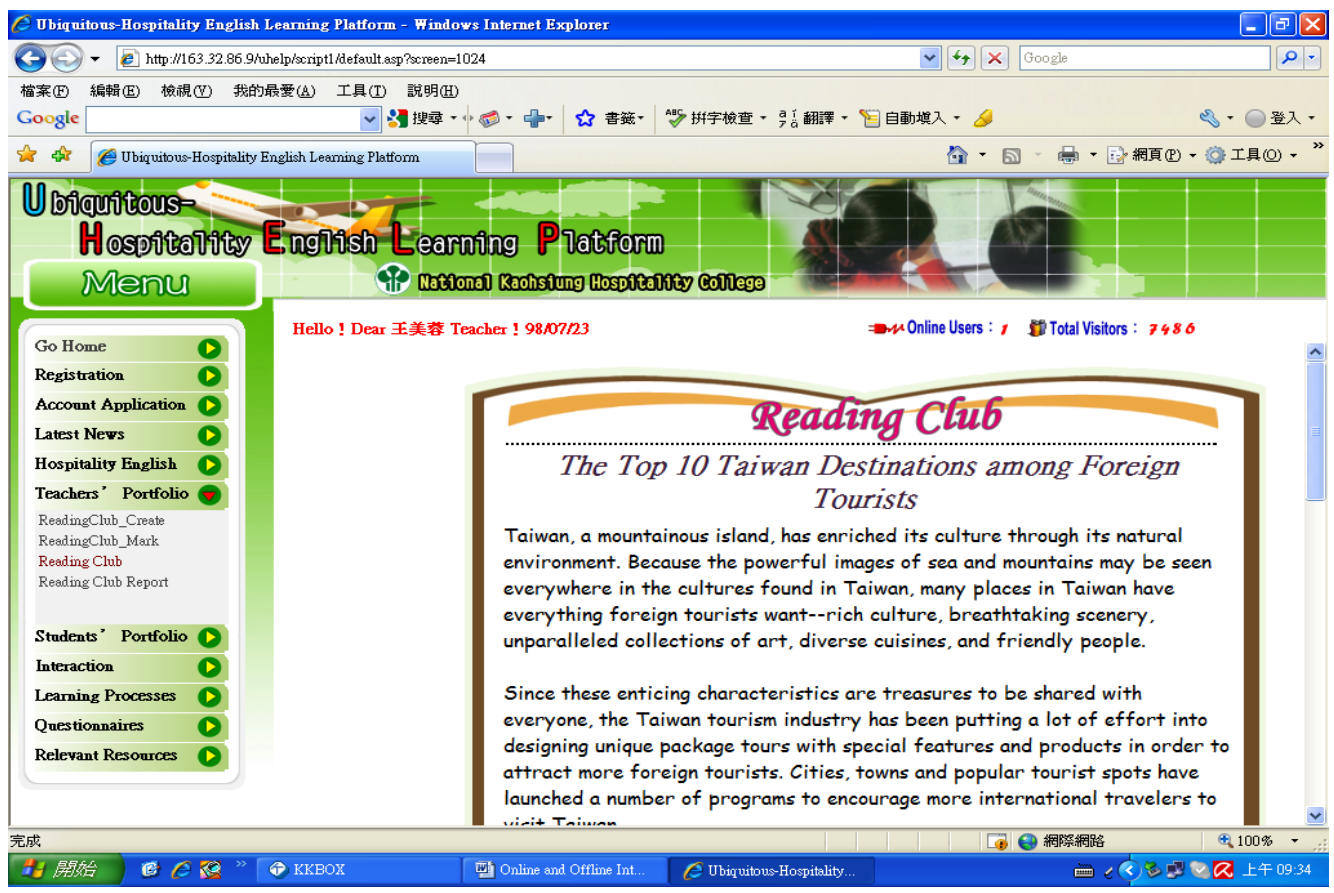

Figure 1: A sample page for a hospitality featured article



Figure 2: A sample page for a project blog 
The instructor monitored the online discussion and gave comments and guidance in class without directly participating in the online group discussion. In other words, the presence of the instructor is limited to the offline context. When the students were conducting the online activities in class, the instructor observed the class atmosphere and took notes. In addition, students were required to write weekly journals to reflect on the classroom atmosphere. The framework of the study is illustrated in Figure 3.



Figure 3: The framework of the study

\section{Data analyses}

The data came from three resources: (1) messages on the weekly post-reading questions on blogs, (2) the instructors' observation notes and (3) the students' weekly journals. The messages generated by the subjects during the ACMC interaction were analysed according to a coding scheme adapted from Curtis and Lawson (2001), to reveal the students' collaborative communicative characteristics. In Curtis and Lawson's coding scheme, there are five major behavioural categories, and under each category are sub-codes. The major behavioural categories are planning, contributing, seeking input, reflecting/monitoring, and social inter-racial interacting socially. The second category, "contributing," is designated as "task-orientated interaction" in Bulu and Yildirim's (2008) study because the codes within this category are related to the reading and discussion activity students performed in the study. In addition, the researcher modified the last part of Curtis and Lawson's coding scheme, social interaction, in which the category is divided into two sub-codes: literal social interaction (LSI) and graphical image (GI). The adapted coding scheme with samples is illustrated in Table 1. The examples within each category of the coding scheme are culled from the data obtained in this study. This coding scheme was used because of the need to identify the classical elements of collaboration in an online environment.

In addition, both the instructors' notes and the students' weekly journals went through a category construction approach (Bogdan \& Biklen, 1992). This approach consists of organisation of the data sources, reduction of the text, and generation of conceptual 
categories by coding units of the data. When the data were examined, coding categories were assigned to the units of data. The emerging categories and samples were presented in Table 2. Unrelated data were deleted during the coding process. After that, the coded data were reported based on the categories generated during the analysis of data. Such a process verified that the instructor did not miss important student-student interactions in the classroom.

Table 1: The coding scheme adapted from Curtis and Lawson (2001)

\begin{tabular}{|c|c|c|c|}
\hline $\begin{array}{l}\text { Behaviour } \\
\text { categories }\end{array}$ & Codes & Description & Examples \\
\hline \multirow[t]{3}{*}{ Planning } & GS & $\begin{array}{l}\text { Group skills: a generic code appl- } \\
\text { ied to expressions that encourage } \\
\text { group activity and cohesiveness. }\end{array}$ & $\begin{array}{l}\text { G1: group1, fighting!!! } \\
\text { G12: GO! GO! GO! } \\
\text { Cheer up everybody }\end{array}$ \\
\hline & OW & $\begin{array}{l}\text { Organising work: Planning group } \\
\text { work; setting shared tasks and } \\
\text { deadlines. }\end{array}$ & $\begin{array}{l}\text { G1: Of course, during discussion, we can } \\
\text { chat about other funny things but } \\
\text { remember to do the task in time. } \\
\text { G12:... I'd like to recommend "Ya-lin" to } \\
\text { be our team leader... I'm sure she's very } \\
\text { good in organising a team. }\end{array}$ \\
\hline & IA & $\begin{array}{l}\text { Initiating activities: Setting up } \\
\text { activities such as chat sessions to } \\
\text { discuss the progress and } \\
\text { organisation of group work. }\end{array}$ & $\begin{array}{l}\text { G4: I hope you can browse the Internet to } \\
\text { discover other translation problem } \\
\text { connected to food and famous attractions } \\
\text { that you haven't understood. }\end{array}$ \\
\hline \multirow{6}{*}{\begin{tabular}{|l|} 
Task- \\
oriented \\
interaction
\end{tabular}} & $\mathrm{HeG}$ & $\begin{array}{l}\text { Help giving: Responding to ques- } \\
\text { tions and requests from others. }\end{array}$ & $\mathrm{N} / \mathrm{A}$ \\
\hline & FBG & $\begin{array}{l}\text { Feedback giving: Providing } \\
\text { feedback on proposals from } \\
\text { others. }\end{array}$ & $\begin{array}{l}\text { G2: Nobody volunteers to be the leader? } \\
\text { Fine... I will be the one. } \\
\text { G4: Yepp! Yor're right }\end{array}$ \\
\hline & RI & $\begin{array}{l}\text { Exchanging resources and } \\
\text { information to assist other group } \\
\text { members. }\end{array}$ & $\begin{array}{l}\text { G4: http:/ / www.taiwan.com.au/Envtra } \\
\text { /WestCentral/ Nantou/ report05.html } \\
\text { This is the most famous attraction, that is } \\
\text { Formosan Aboriginal Culture Village. I } \\
\text { think everyone would like it. }\end{array}$ \\
\hline & SK & $\begin{array}{l}\text { Sharing knowledge: Sharing } \\
\text { existing knowledge and } \\
\text { information with others. }\end{array}$ & $\begin{array}{l}\text { G4: I think "mala hot post" is strange. } \\
\text { G5: I think the hotels in Taiwan should } \\
\text { accept different culture from everywhere } \\
\text { because there are much to with culture in } \\
\text { hotel industry. }\end{array}$ \\
\hline & $\mathrm{Ch}$ & $\begin{array}{l}\text { Challenging others: challenging } \\
\text { the contributions of other } \\
\text { members and seeking to engage in } \\
\text { debate. }\end{array}$ & $\begin{array}{l}\text { G8: Hot tea??? Are you live hotel which } \\
\text { not provide hot tea with you? }\end{array}$ \\
\hline & Ex & $\begin{array}{l}\text { Explaining or elaborating: } \\
\text { Supporting one's own position } \\
\text { (possibly following a challenge). }\end{array}$ & $\begin{array}{l}\text { G10: They are unique and efficacious. } \\
\text { Besides, there are varieties of famous } \\
\text { snacks. They are delicious. } \\
\text { G7: ... Because this building can represent } \\
\text { Taiwan. }\end{array}$ \\
\hline \multirow[t]{3}{*}{$\begin{array}{l}\text { Seeking } \\
\text { input }\end{array}$} & $\mathrm{HeS}$ & $\begin{array}{l}\text { Help seeking: Seeking assistance } \\
\text { from others. }\end{array}$ & $\mathrm{N} / \mathrm{A}$ \\
\hline & FBS & $\begin{array}{l}\text { Feedback seeking: seeking } \\
\text { feedback to a position advanced. }\end{array}$ & $\begin{array}{l}\text { G6: Nobody has idea? } \\
\text { G3: Sorry if you want to share the ideas, } \\
\text { please go to Week Two. }\end{array}$ \\
\hline & Ef & $\begin{array}{l}\text { Advocating effort: Urging others } \\
\text { to contribute to the group effort. }\end{array}$ & $\begin{array}{l}\text { G1: Dear Group } 1 \\
\text { Please don't be shy... } \\
\text { Post your reply here, Karen and Jocelyn. }\end{array}$ \\
\hline
\end{tabular}




\begin{tabular}{|l|l|l|l|}
\hline $\begin{array}{l}\text { Reflection } \\
\text { /monit- } \\
\text { oring }\end{array}$ & ME & $\begin{array}{l}\text { Monitoring group effort: } \\
\text { Comments about the group's } \\
\text { processes and achievements. }\end{array}$ & $\begin{array}{l}\text { G11: what happened here!!???? } \\
\text { No one's replying ... what an awkward } \\
\text { situation? } \\
\text { G9: Celia } \\
\text { Only two people }\end{array}$ \\
\cline { 2 - 4 } & RM & $\begin{array}{l}\text { Reflecting on medium: Comments } \\
\text { about the effectiveness of the } \\
\text { medium in supporting group } \\
\text { activities. }\end{array}$ & $\begin{array}{l}\text { G8: Sorry abut posting so many times, the } \\
\text { reason why is that the program error. }\end{array}$ \\
\hline $\begin{array}{l}\text { Social } \\
\text { interaction }\end{array}$ & LSI & $\begin{array}{l}\text { Literal social interaction: } \\
\text { Conversation about social matters } \\
\text { that is unrelated to the group task. } \\
\text { This activity helps to 'break the } \\
\text { ice.' }\end{array}$ & $\begin{array}{l}\text { G3: Hello! Nice to meet you. } \\
\text { G7: Oh..sorry... } \\
\text { Thanks to Lucy for helping us! } \\
\text { There's a classmate's Chinese name just } \\
\text { similar like yours... }\end{array}$ \\
\cline { 2 - 3 } & GI & $\begin{array}{l}\text { Graphical image: Emotional } \\
\text { expression by graphical images }\end{array}$ & G12: 8 \\
\hline
\end{tabular}

Table 2: Categories and samples of class observation and weekly journals $\mathrm{CO}=$ class observation, $\mathrm{WJ}=$ weekly journals

\begin{tabular}{|c|c|}
\hline & Samples \\
\hline \multirow[t]{2}{*}{$\begin{array}{l}\text { Struggling with } \\
\text { platform } \\
\text { operations }\end{array}$} & $\begin{array}{l}\text { CO: Students in College A were familiar with the operation of the platform } \\
\text { while a few of College B students still felt confused and unfamiliar with the } \\
\text { function of U-HELP. (Week 3) }\end{array}$ \\
\hline & $\begin{array}{l}\text { WJ: I spent a lot of time learning how to use the platform. Sometimes I still } \\
\text { cannot find the function I need. (Week } 2 \text { ) }\end{array}$ \\
\hline \multirow[t]{2}{*}{$\begin{array}{l}\text { Handling technical } \\
\text { problems }\end{array}$} & $\begin{array}{l}\text { CO: Two or three students in College A were facing the technical difficulties } \\
\text { when submitting their blog replies. (Week 2) }\end{array}$ \\
\hline & $\begin{array}{l}\text { WJ: My classmates are willing to help me with the technical problems, } \\
\text { which make me more confident. (Week 1) }\end{array}$ \\
\hline \multirow{2}{*}{$\begin{array}{l}\text { Passive attitudes } \\
\text { towards the entire } \\
\text { procedure }\end{array}$} & $\begin{array}{l}\text { CO: One thirds of students in College B seemed to pay no interests towards } \\
\text { this online activity. (Week 1) }\end{array}$ \\
\hline & $\begin{array}{l}\text { WJ: It took me too much time to read and answer the discussion questions. } \\
\text { Sometimes I am too lazy to do that. (Week 3) }\end{array}$ \\
\hline \multirow[t]{2}{*}{$\begin{array}{l}\text { Tense atmosphere } \\
\text { in class }\end{array}$} & $\begin{array}{l}\text { CO: Students in College B were unfamiliar with the instructor as well as the } \\
\text { platform, so the interaction among them was uneasy and not as good as the } \\
\text { interaction with College A students. (Week 1) }\end{array}$ \\
\hline & $\begin{array}{l}\text { WJ: There are many tasks each time and the time is short, so I feel stressed. } \\
\text { (Week 2) }\end{array}$ \\
\hline \multirow[t]{2}{*}{$\begin{array}{l}\text { Engagement in } \\
\text { tasks }\end{array}$} & $\begin{array}{l}\text { CO: Although students in College B were unfamiliar with the blog function, } \\
\text { they seemed to have a great relish to group blogging as soon as the TA } \\
\text { demonstrated the function of group blog from the platform. (Week 1) }\end{array}$ \\
\hline & $\begin{array}{l}\text { WJ: I am excited to have the chance to learn with others, especially students } \\
\text { form other college. I like to discuss in the blog with them. (Week 2) }\end{array}$ \\
\hline
\end{tabular}

The above data were coded by the researcher and her assistant (Master's degree in TESOL), inter-rater reliability between the two coders was kappa $=0.71$. According to Altman, (1991), values between 0.60 and 0.80 may be taken to represent substantial agreement beyond chance. The value of this study can be interpreted as substantial agreement. Afterwards, the two coders discussed the discrepancies in the categorisation of the items one by one until agreement on categorisation was reached. 


\section{Results and discussions}

Transcripts of the messages posted to the blog server were the principal data source for the first research question: What are the online collaborative characteristics of the two groups of students? The results are shown in Table 3. Two prominent communicative behaviors in this study are social interaction (SI) (42\% of the total postings) and taskoriented interaction (TI) $(40 \%$ of the total postings). The other three categories were comparatively low. Planning was fairly low, at $7.1 \%$, and seeking input was only slightly higher, at $8.8 \%$. Reflection and monitoring was the lowest, accounting for only $2.6 \%$ of the total coded data. There were few exchanges seeking to monitor group effort or reflecting on the use of the medium.

Table 3: Subjects' online collaborative behaviours

\begin{tabular}{|c|c|c|c|c|}
\hline \multicolumn{2}{|r|}{ Online collaborative behaviours } & Code totals & Code $(\%)$ & Total (\%) \\
\hline \multirow[t]{3}{*}{ Planning } & Group skills & 13 & 2.4 & \multirow[t]{3}{*}{7.1} \\
\hline & Organising work & 22 & 4.1 & \\
\hline & Initiating activities & 3 & 0.6 & \\
\hline \multirow{5}{*}{$\begin{array}{l}\text { Task-oriented } \\
\text { interaction }\end{array}$} & Feedback giving & 55 & 10.3 & \multirow[t]{5}{*}{39.5} \\
\hline & Exchanging resources and information & 6 & 1.1 & \\
\hline & Sharing knowledge & 117 & 21.9 & \\
\hline & Challenging others & 5 & 0.9 & \\
\hline & Explaining or elaborating & 28 & 5.2 & \\
\hline \multirow[t]{2}{*}{ Seeking input } & Feedback seeking & 44 & 8.2 & \multirow[t]{2}{*}{8.8} \\
\hline & Advocating effort & 3 & 0.6 & \\
\hline \multirow{2}{*}{$\begin{array}{l}\text { Reflection/ } \\
\text { monitoring }\end{array}$} & Monitoring group effort & 11 & 2.2 & \multirow[t]{2}{*}{2.6} \\
\hline & Reflecting on medium & 3 & 0.6 & \\
\hline \multirow{2}{*}{$\begin{array}{l}\text { Social } \\
\text { interaction }\end{array}$} & Literal social interaction & 172 & 32.2 & \multirow[t]{2}{*}{41.9} \\
\hline & Graphical image & 52 & 9.7 & \\
\hline Total & & 534 & $100 \%$ & $100 \%$ \\
\hline
\end{tabular}

The above results are different from Curtis and Lawson's (2001) study, in which approximately equal distribution of the behaviours of planning, task-oriented interaction, seeking input, reflection/monitoring was found. Moreover, SI, the top frequency of all the behaviours in this study, ranked as the lowest frequency $(4 \%)$ of all the behaviours in their study. Possible explanations are that students in distance education programs need to build up the sense of community to attract and retain learners (Rovi, 2001). Accordingly, students in this study employed SI the most frequently. Within SI, literal social interaction appeared 172 times (32\% of the total utterance), which included simple greetings such as " $\mathrm{Hi}$, nice to meet you" and "How's everything?" In addition, graphic images expressing their mood, such as were found. As Vonderwell (2002) suggests, due to the absence of social cues such as body language, ASMC might minimise the richness of communication and impede student learning. The use of those graphic images in this study might be a supplement to the absence of social cues. These kinds of social interactions in the blogs helped the two groups break the ice and maintain the interaction. Consequently, the sense of community could be sustained.

With regard to task-oriented interaction, sharing knowledge (SK) and feedback giving (FBG) are the first and the second, respectively, in terms of frequency. Owing to the design of the project, participants were required to answer and discuss weekly postreading questions; therefore, it is perfectly reasonable to see the high frequency of knowledge sharing and feedback giving among their discussion processes. The low 
percentage of the other categories might be attributed to the short period of the project. Students might have been devoting most of their time to the task and lacked time to reflect on their learning. Another possible explanation for this phenomenon may be the manner in which English teaching and learning are approached in Taiwan, tending to be test-oriented and decontextualised (Shih \&Yang, 2008). In Taiwan, discrete grammar practice and mechanical drills are the focus of most English classes prior to college level, which exacerbates learners' lack of confidence and language competence in communicating with others in English. Similar results are reported by Tse, Yuen, Loh, Lam, and Ng (2010), and Liu and Jackson (2008). Tse, Yuen, Loh, Lam, and Ng found that primary school students in Hong Kong did not have sufficiently high English reading proficiency to cope with and comprehend advanced English blogs. In Liu and Jackson's (2008) study, the unwillingness of Chinese undergraduate, nonEnglish majors to communicate and their foreign language anxiety correlated significantly with each other and with their self-rated English proficiency.

Table 4: Groups' online collaborative behaviours

\begin{tabular}{|c|c|c|c|c|c|c|c|}
\hline \multirow{2}{*}{\multicolumn{2}{|c|}{$\begin{array}{l}\text { Group codes } \\
\text { A: NKHC } \\
\text { B: NTIT }\end{array}$}} & \multicolumn{6}{|c|}{ Behaviours } \\
\hline & & \multirow{2}{*}{$\begin{array}{c}\text { Planning } \\
4\end{array}$} & \multirow{2}{*}{$\begin{array}{c}\text { Task-oriented } \\
\text { interaction }\end{array}$} & \multirow{2}{*}{$\begin{array}{c}\begin{array}{c}\text { Seeking } \\
\text { input }\end{array} \\
4\end{array}$} & \multirow{2}{*}{$\begin{array}{l}\text { Reflection/ } \\
\text { monitoring } \\
2\end{array}$} & \multirow{2}{*}{$\begin{array}{c}\begin{array}{c}\text { Social } \\
\text { interaction }\end{array} \\
21\end{array}$} & \multirow{2}{*}{$\begin{array}{c}\begin{array}{c}\text { Total } \\
\text { (frequency) }\end{array} \\
39\end{array}$} \\
\hline G1 & A & & & & & & \\
\hline & B & 0 & 16 & 2 & 0 & 13 & 31 \\
\hline \multirow[t]{2}{*}{ G2 } & $\mathrm{A}$ & 3 & 14 & 4 & 0 & 2 & 23 \\
\hline & B & 0 & 9 & 2 & 0 & 4 & 15 \\
\hline \multirow[t]{2}{*}{ G3 } & A & 2 & 14 & 4 & 0 & 6 & 26 \\
\hline & B & 1 & 6 & 2 & 0 & 4 & 13 \\
\hline \multirow[t]{2}{*}{ G4 } & $\mathrm{A}$ & 1 & 9 & 2 & 2 & 10 & 24 \\
\hline & B & 1 & 18 & 1 & 0 & 5 & 25 \\
\hline \multirow[t]{2}{*}{ G5 } & $\mathrm{A}$ & 0 & 3 & 0 & 0 & 5 & 8 \\
\hline & $\mathrm{B}$ & 0 & 2 & 1 & 0 & 7 & 10 \\
\hline \multirow[t]{2}{*}{ G6 } & $\mathrm{A}$ & 0 & 11 & 3 & 0 & 8 & 22 \\
\hline & $\mathrm{B}$ & 0 & 7 & 1 & 0 & 4 & 12 \\
\hline \multirow[t]{2}{*}{ G7 } & $\mathrm{A}$ & 1 & 13 & 2 & 0 & 7 & 23 \\
\hline & $\mathrm{B}$ & 3 & 7 & 1 & 0 & 16 & 27 \\
\hline \multirow[t]{2}{*}{ G8 } & $\mathrm{A}$ & 0 & 7 & 2 & 0 & 21 & 30 \\
\hline & $\mathrm{B}$ & 1 & 9 & 1 & 0 & 3 & 14 \\
\hline \multirow[t]{2}{*}{ G9 } & $\mathrm{A}$ & 2 & 11 & 4 & 4 & 24 & 45 \\
\hline & $\mathrm{B}$ & 0 & 3 & 1 & 0 & 4 & 8 \\
\hline \multirow[t]{2}{*}{ G10 } & $\mathrm{A}$ & 3 & 15 & 4 & 1 & 9 & 32 \\
\hline & B & 0 & 2 & 0 & 0 & 0 & 2 \\
\hline \multirow[t]{2}{*}{ G11 } & $\mathrm{A}$ & 3 & 4 & 0 & 2 & 10 & 20 \\
\hline & B & 0 & 4 & 1 & 0 & 2 & 7 \\
\hline \multirow[t]{2}{*}{ G12 } & $\mathrm{A}$ & 5 & 13 & 3 & 3 & 28 & 52 \\
\hline & B & 8 & 6 & 2 & 0 & 10 & 26 \\
\hline Totals & & 38 & 211 & 47 & 146 & 224 & 534 \\
\hline$(\%)$ & & 7.1 & 39.5 & 8.8 & 2.6 & 41.9 & 100 \\
\hline
\end{tabular}

Concerning group performance, there was a wide range in the frequency of interaction across the 12 groups, from 18 to 78 postings (Table 4). Within each group, there was also variation in the pattern of contribution, similar to that reported in Curtis and Lawson's study. Generally speaking, students from College A posted more frequently than students from College B (especially for G9, G10, and G11). Take Group 10 for example: although students from College A contributed 32 posting, students from College B made only 2 postings. In this case, online interaction between the two 
colleges did not occur. However, when there was no response from College B, the group members from College A continued the discussion on their own. For more successful interaction, the four groups G1, G4, G7, and G12 are illustrative. Here "successful interaction" is defined as more exchanges among students from both colleges. G1 and G12 provided the most successful discussion results regardless of their various discussion patterns. The results from offline interaction might account for the unequal distribution of the online contributions to a certain extent.

Now, let us turn to the second research question. Students' offline interaction in class was observed and their weekly journals were analysed. The results were shown in Table 5. The interactions among offline peers were classified into five major categories: struggling with platform operation, handling technical problems, passive attitudes towards the procedure, tense atmosphere in class, and engagement in tasks. Each V stands for one to five times. For instance, in the first week, struggling with platform operation was identified five times in College $\mathrm{A}$, so a $\mathrm{V}$ was given while it occurred fourteen times in College B, so three Vs were given. Therefore, the higher the frequency of the situation, the more Vs were given. In contrast, if the situation did not exist, an X was shown in the column instead.

Table 5: Results of the class observation

\begin{tabular}{|l|l|l|l|l|}
\hline \multicolumn{1}{|c|}{ Category } & \multicolumn{1}{|c|}{ Schools } & \multicolumn{1}{|c|}{ Week 1 } & \multicolumn{1}{|c|}{ Week 2 } & Week 3 \\
\hline Struggling with platform operations & College A & V & X & X \\
\cline { 2 - 5 } & College B & VVV & VV & V \\
\hline \multirow{2}{*}{ Handling technical problems } & College A & V & V & X \\
\cline { 2 - 5 } & College B & VV & VV & VV \\
\hline Passive attitudes towards the procedure & College A & X & V & VV \\
\cline { 2 - 5 } & College B & VV & VV & V \\
\hline \multirow{2}{*}{ Tense atmosphere in class } & College A & V & X & X \\
\cline { 2 - 5 } & College B & VVV & V & X \\
\hline Engagement in tasks & College A & VV & VVV & VV \\
\hline & College B & V & VV & VV \\
\hline
\end{tabular}

Starting with the first category, struggling with platform operations, we can see that the condition remained in College $B$ for three weeks despite the decrease of the frequency. On the contrary, the low frequency found in the first week among students in College A remained low throughout the following weeks. Students in College A had used some functions in the platform for other activities; hence, they needed less time to familiarise themselves with the U-HELP compared with students in College B. The situation was slightly different in dealing with technical problems. Technical problems occurred more frequently in College B than in College A. Even by the third week, the technical problems did not disappear.

The technical problems might have resulted from the instability of the network systems or equipment of the colleges and thus hindered students' interaction. It is not surprising that learners become dissatisfied and lose their interest and motivation necessary to continue the tasks when the technology frequently breaks down or programs crash (Herrington \& Oliver, 1997; Hoven, 2003). Several researchers have found that learners' perceived value of their learning experience using technology partially depends on the transparency and robustness of the technology (Downes, 2000; Hoven, 2003). Hara and Kling (1999) indicated that technical problems often result in students' disillusionment with web based distance learning. Liu and Yin (2006) also suggested that insufficient computer skills may reduce the effectiveness of 
online learning. Furthermore, these factors might account for the tense atmosphere found in class during the first week. The interaction was awkward and students felt uneasy, especially for students in College B. Both the U-HELP and the instructor were new to this large class. In contrast, it took students in College A only one week to get accustomed to the instructor and the activity. This was most likely the major factor contributing to the low frequency of blog replies and participants' negative attitudes towards the ACMC activity.

Despite the above problems, participants' cooperation in handling technical problems was found in class. Participants from the two schools cooperated with their offline peers very well during the first week. Whenever encountering technical difficulties in the login or uploading process, participants assisted each other. This situation occurred frequently in the first week in both schools. However, students in College A confronted fewer technical problems in class, so the need for cooperation decreased in the following two weeks. Similarly, students in College B were willing to help each other solve the technical problems.

The third category in Table 5 shows that students in College B had more negative attitudes towards the activity at the beginning; however, the severity of their negative feelings decreased by the third week. The frequency of interaction among participants is widely acknowledged to be an indicator of successful online learning experiences. At the beginning, unfamiliarity with platform operation resulted in low frequency of blog responses in both schools. Not many students in College B gave feedback on blogs since they were less familiar with the U-HELP. The interactions between the two schools improved in the second week, but in the third week the feedback given to the students in College A diminished again. This phenomenon probably resulted from the participants' lack of interest or motivation, and it can also be attributed to the participants' negative attitudes towards the entire procedure.

In spite of the participants' negative attitudes in class, a substantial number of the participants had good engagement in positive reactions toward the tasks. In the first week, students in College A were enthusiastic about the opportunity to partake in online activities with students from the other school, and seemed to be more excited about these activities than students in College B. In class observation showed students in College B followed the instructions and seemed well engaged in the online activities in spite of the low frequencies of their blog replies. As they became more familiar with U-HELP, students in College B showed a greater level of engagement in the activities. As for the students in College A, they engaged in the tasks most during the second week, but their enthusiasm declined in the third week due to a lack of responses from College B.

The features of the offline interaction echo the findings of the first research question. Collaboration and engagement were found in both online and offline settings. However, students encountered problems of networking systems and suffered from the tense atmosphere in the classroom, which might partially explain why they neglected the learning process such as planning and reflecting. Although more sophisticated research should be designed addressing the relationship between online and offline interaction in blended learning, we can infer that offline interaction such as the classroom atmosphere and the participants' affective factors could influence the enhancement of reflective process claimed by ACMC (An \& Frick, 2006) and the sustainability of motivation toward online interaction to a certain extent. In addition, 
how to promote students' intrinsic motivation toward the asynchronous communication is an area worth more research.

\section{Conclusions and implications}

The characteristics associated with online collaborative communication and offline interaction are identified in the present study. However, the proportions of characteristics are different from previous studies. In addition to social interaction and task-oriented interaction, students in this study did not pay much attention to planning the group discussion, seek input, and monitor/reflect on the process. With regard to group dynamic, students from College A posted more frequently than students from College B did, but a wide range in the frequency of interaction across the 12 groups was found in this study. In class observation revealed the tense atmosphere and problems related to handling the activity in offline interactions. The offline interactions in carrying out the ACMC activities in the classrooms were sorted into five major categories: struggling with platform operation, handling technical problems, passive attitudes towards the procedure, tense atmosphere in class, and engagement in tasks.

Compared to a traditional instructional model, the implementation of ICT tools in blended learning does promote social interaction among students and their engagement and thus a more learner-centered learning environment was created by means of integrating e-learning elements. However, it does not automatically facilitate students in their adoption of active learning strategies. The roles group members ought to play should be recognised to promote effective and efficient online/offline interaction. Moreover, the problematic aspects of networked learning result in negative attitudes of students in offline interaction in class, which may in turn incur insufficient online interaction and impair students' learning.

Based on the findings, some pedagogical implications are presented. For effective interaction in both online and offline settings, instructors should take account of students' characteristics and their technical and learning competencies. As Donnelly and McSweeney (2008) suggest, instructors should trigger students into the employment of e-tools for formal learning activities and provide them with required support to master the competencies governing effective and collaborative online learning. Moreover, teachers who devote themselves to e-learning from sociocultural perspectives should take care of pedagogical techniques such as carefully grouping students and constantly guiding students for effective interaction (Kitade, 2008; Pawan et al., 2003).

Key competencies such as how to work electronically within a group and how to harness ICT tools should be instructed, especially for students accustoming to traditional learning methods. Specifically, reflective practice for a person to use reflective processes to critically analyse, reappraise, and learn from experiences (Bulman \& Schutz, 2004; Redmond, 2004) should be advocated, to help students adopt virtual learning methods, work collaboratively online, and maximise learning outcomes. By so doing, students may increase their metacognitive awareness of the learning process and strategise ways to achieve the pedagogical goals of the tasks assigned (in this case, hospitality culture exchange and language learning) instead of the epiphenomena arising in the process of task completion (Belz, 2002). 
To promote the success of blended learning, the social interdependence among the participants, the tasks assigned, and the e-learning tools remain challenging for teachers. For future research, a longitudinal study, as suggested by Farmer, Yue and Brooks (2008) who used blogging for higher order learning, could be designed to monitor students' use of online communication patterns and evaluate the impact of the adoption of technology on classroom interaction. In addition, classroom interaction could be recorded for more accurate data analyses to reveal how offline interaction influences online learning. Moreover, empirical study with pre- and post-tests could be designed to investigate the extent to which learners retain the co-constructed knowledge and also the extent to which e-learning application with different tasks facilitates language learning. Finally, as one reviewer pointed out, the online interactions in this study took place mainly within groups rather than between groups and this phenomenon could result from the mandatory requirement to discuss with their group mates and the optional requirement to discuss with other groups. Further research can be conducted to examine how the online tasks should be designed to excite students' interests in online discussion and in turn arouse their intrinsic motivation to benefit from blended learning.

\section{Acknowledgments}

An earlier version of this paper was presented at the conference, The First International Conference on Popular Culture and Education in Asia, held at the Hong Kong Institute of Education by the support of National Science Council (NSC 97-2914I-328-002-A1). The author would like to thank the students who participated in this project and the research assistant Sandra Yang for collecting and analysing the data.

\section{References}

Abrams, Z. I. (2003). The effect of synchronous and asynchronous CMC on oral performance in German. The Modern Language Journal, 87, 157-167.

Althaus, S. (1996). Computer-mediated communication in the university classroom: An experiment with on-line discussions. Communication Education, 46, 158-174.

An, Y.-J. \& Frick, T. (2006). Student perceptions of asynchronous computer-mediated communication in face-to-face courses. Journal of Computer-Mediated Communication, 11(2), article 5. http:/ / jcmc.indiana.edu/vol11/issue2/ an.html

Belz, A. J. (2002). Social dimension of telecollaborative foreign language study. Language Learning E Technology, 6(1), 61-80. http:/ /llt.msu.edu/vol6num1/belz/default.html

Belz, A. J. \& Kinginger, C. (2002). The cross-linguistic development of address form use in telecollaborative language learning: Two case studies. The Canadian Modern Language Review, 59(2), 189-214.

Berg, E. C. (1999). The effects of trained peer response on ESL students' revision types and writing quality. Journal of Second Language Writing, 8(3) 215-241.

Birch, D. \& Volkov, M. (2007). Assessment of online reflections: Engaging English second language (ESL) students. Australasian Journal of Educational Technology, 23(3), 291-306. http: / / www.ascilite.org.au/ajet/ajet23/birch.html

Blake, R. J. (2005). Bimodal CMC: The glue of language learning at a distance. CALICO Journal, 22(3), 497-511. [verified 16 Oct 2010] https:/ / www.calico.org/a-146-Bimodal $\% 20 \mathrm{CMC} \% 20$ The $\%$ 20Glue $\% 20$ of $\% 20$ Language $\% 20$ Learning $\% 20$ at $\% 20$ a $\% 20$ Distance.html 
Bogdan, R. C. \& Biklen, S. K. (1992). Qualitative research for education: An introduction to theory and methods. Boston: Allyn \& Bacon.

Bonk, C. \& Graham, C. (2005). The handbook of blended learning: Global perspectives, local designs. New York: Jossey Bass.

Branon, R. F. \& Essex, C. (2001). Synchronous and asynchronous communication tools in distance education: A survey of instructors. TechTrends, 45, 36-42.

Bulman, C. \& Schutz, S. (2004). Reflective practice in nursing (3rd ed.). Oxford: Blackwell.

Bulu, S. T. \& Yildirim , Z. (2008). Communication behaviors and trust in collaborative online teams. Journal of Educational Technology \& Society, 11(1), 132-147. http://www.ifets.info/journals/11_1/10.pdf

Chen, W. \& Looi, C.-K. (2007). Incorporating online discussion in face to face classroom learning: A new blended learning approach. Australasian Journal of Educational Technology, 23(3), 307326. http:/ / www.ascilite.org.au/ajet/ajet23/chen.html

Chun, D. (1994). Using computer networking to facilitate the acquisition of interactive competence. System, 22, 17-31.

Curtis. D. \& Lawson, M. (2001). Exploring collaborative online learning. Journal of Asynchronous Learning Networks, 5(1), 21-34.

DeSanctis, G. \& Monge, P. (1998). Communication processes for virtual organizations. Journal of Computer-Mediated Communication, 3(4). [viewed 3 Jun 2008, verified 17 Oct 2010] http:/ / www3.interscience.wiley.com/ cgi-bin/fulltext/120837743/ HTMLSTART

Donnelly, R. \& McSweeney, F. (2008). Applied e-learning and e-teaching in higher education. London: Information Science Reference.

Downes, S. (2000). Nine rules for good technology. [viewed 16 Oct 2000, verified 17 Oct 2010] http: / / technologysource.org/article/nine_rules_for_good_technology /

Edwards, C. \& Willis, J. (2005). Teachers exploring tasks in English language teaching. Basingstoke, Hampshire: Palgrave Macmillan.

Felix, U. (2002). The web as vehicle for constructivist approaches in language teaching. ReCALL, $14(1), 2-15$

Farmer, B., Yue, A. \& Brooks, C. (2008). Using blogging for higher order learning in large cohort university teaching: A case study. Australasian Journal of Educational Technology, 24(2), 123136. http:/ / www.ascilite.org.au/ajet/ajet24/farmer.html

Ferdig, R. E. \& Trammell, K. D. (2004). Content delivery in the 'blogosphere'. THE Journal, 31(7), 12-20. [viewed 27 Jan 2007, verified 17 Oct 2010] http:/ / thejournal.com/articles/ 16626

Ginns, P. \& Ellis, R. (2009). Evaluating the quality of e-learning at the degree level in the student experience of blended learning. British Journal of Educational Technology, 40(4), 652-663.

Guzdial, M. \& Turns, J. (2000). Effective discussion through a computer-mediated anchored forum. Journal of the Learning Sciences, 9(4), 437-470.

Hanson-Smith, E. (1997). Technology in the classroom: Practice and promise in the 21st century. [viewed 6 Mar 2000, verified 17 Oct 2010] http: / / www.tesol.org/s_tesol/ sec_document.asp?CID=403\&DID=1064

Hara, N. \& Kling, R. (1999). Students' frustrations with a Web-based distance education course. First Monday, 4(12).

http: / firstmonday.org/htbin/cgiwrap/bin/ojs/index.php/fm/article/view / 710/620

Herrington, J. \& Oliver, O. (1997). Multimedia, magic and the way students respond to a situated learning environment. Australian Journal of Educational Technology, 13(2), 127-143.

http: / / www.ascilite.org.au/ajet/ajet13/herrington.html 
Hoven, D. (2003). Strategic uses of CALL: What learners use and how they react. Australian Review of Applied Linguistics, Series S No. 17, 125-147. http:/ / eprints.qut.edu.au/7653/

Hoven, D. (2006). Communicating and interacting: An exploration of the changing roles of media in CALL/CMC. Computer Assisted Language Instruction Consortium Journal, 23(2), 233256. [verified 17 Oct 2010] https: / / www.calico.org/a-114Communicating $\% 20$ and $\% 20$ Interacting $\% 20 \mathrm{An} \% 20$ Exploration $\% 20 \mathrm{of} \% 20$ the $\% 20$ Changing $\% 2$ 0Roles $\% 20$ of $\%$ 20Media $\% 20$ in \%20CALL/CMC.html

Hourigan, T. \& Murray, L. (2010). Using blogs to help language students to develop reflective learning strategies: Towards a pedagogical framework. Australasian Journal of Educational Technology, 26(2), 209-225. http:/ / www.ascilite.org.au/ajet/ ajet26/hourigan.html

Hrastinski, S. (2009). A theory of online learning as online participation. Computers $\mathcal{E}$ Education, 52(1), 78-82.

Kern, R. G. (1995). Restructuring classroom interaction with networked computers: Effects on quantity and characteristics of language production. Modern Language Journal, 79, 457-476.

Kern, R. G. \& Warschauer, M. (2000). Theory and practice of network-based language teaching. In M. Warschauer \& R. Kern (Eds.), Network-based language teaching: Concepts and practice (pp. 1-19). Cambridge, England: Cambridge University Press.

Kitade, K. (2008). The role of offline metalanguage talk in asynchronous computer-mediated communication. Language Learning \& Technology, 12(1), 64-84. http: / / llt.msu.edu/vol12num1/kitade/ default.html

Levy, M. \& Kennedy, C. (2004). A task-cycling pedagogy using stimulated reflection and audioconferencing in foreign language learning. Language Learning $\mathcal{E}$ Technology, 8(2), 50-68. http: / /lt.msu.edu/vol8num2/levy/ default.html

Liu, S. H. \& Yin, M. C. (2006). A study of improve learning understanding and develop instructional strategies in asynchronous learning. Curriculum \& Instruction Quarterly, 9(4), 155-176.

Liu, M. \& Jackson, J. (2008). An exploration of Chinese EFL learners' unwillingness to communicate and foreign language anxiety. The Modern Language Journal, 92(1), 71-86.

Loewen, S. \& Erlam, R. (2006). Corrective feedback in the chatroom: An experimental study. Computer Assisted Language Learning, 19(1), 1-14.

Lomicka, L., Lord, G., Ducate, L. \& Arnold, N. (2007). Teaching, learning and collaborating: A foreign language teacher wiki community. Paper presented at the annual conference of the Computer Assisted Language Instruction Consortium, Texas State University, San Marcos, TX.

Meyer, K. A. (2004). Evaluating online discussions: Four different frames of analysis. Journal of Asynchronous Learning Networks, 8(2), 101-114.

Moisseeva, M., Steinbeck, R. \& Seufert, S. (2007). Online learning communities and collaborative learning. [viewed 12 Jan 2008, verified 17 Oct 2010] http:/ / www.iienetwork.org/ ?p=41543

Murphy, E. (2004). An instrument to support thinking critically about critical thinking in online asynchronous discussions. Australasian Journal of Educational Technology, 20(3), 295-315. http: / / www.ascilite.org.au/ajet/ajet20/murphy.html

$\mathrm{Ng}$, C. S. L. \& Cheung, W. S. (2007). Comparing face to face, tutor led discussion and online discussion in the classroom. Australasian Journal of Educational Technology, 23(4), 455-469. http: / / www.ascilite.org.au/ajet/ajet23/ng.html

O'Down, R. (2007). Evaluating the outcomes of online intercultural exchange. ELT Journal, 61(2), 144-152.

Ortega, L. (1997). Processes and outcomes in networked classroom interaction: Defining the research agenda for L2 computer-assisted classroom discussion. Language Learning $\mathcal{E}$ Technology, 1(1), 82-93. http:/ / llt.msu.edu/vol1num1/ ortega/default.html 
Pawan, F., Paulus, T. M., Yalcin, S. \& Chang, C.-F. (2003). Online learning: Patterns of engagement and interaction among in-service teachers. Language Learning $\mathcal{E}$ Technology, 7(3), 119-140. http: / /ltt.msu.edu/vol7num3/pdf/pawan.pdf

Payne, J. S. \& Ross, B. M. (2005). Synchronous CMC, working memory, and L2 oral proficiency development. Language Learning \& Technology, 9(3), 35-54. http: / /lit.msu.edu/vol9num3/payne/default.html

Redmond, B. (2004). Reflection in action: Developing reflective practice in health and social services. Aldershot: Ashgate Publishing.

Roblyer, M. D., \& Wiencke, W. R. (2004). Exploring the interaction equation: Validating a rubric to assess and encourage interaction in distance courses. Journal of Asynchronous Learning Networks, 8(4).

Romiszowski, A. \& Mason, R. (2004). Computer-mediated communication. In D. H. Jonassen (Ed.), Handbook of research for educational communications and technology, 2nd ed. (pp. 397-431). New York: Macmillan.

Rovai, A. P. (2001). Classroom community at a distance - a comparative analysis of two ALNbased university programs. The Internet and Higher Education, 4, 105-118.

Schellens, T. \& Valcke, M. (2006). Fostering knowledge construction in university students through asynchronous discussion groups. Computers $\mathcal{E}$ Education, 46, 349-370.

Self, J. A., Karakirik, E., Kor, A. L., Tedesco, P. \& Dimitrova, V. (2000). Computer-based strategies for articulate reflection. In Young, S. S., Greer, J., Maurer, H. \& Chee, Y. S. (Eds), Proceedings of the International Conference on Computers in Education/International Conference on Computer-Assisted Instruction, pp.3-12.

Shih, Y.-C. \& Yang, M.-T. (2008). A collaborative virtual environment for situated language learning using VEC3D. Educational Technology \& Society, 11(1), 56-68. http:/ / www.ifets.info/journals/11_1/5.pdf

Tse, S. K., Yuen, A. H. K., Loh, E. K. Y., Lam, J. W. I. \& Ng, R. H. W. (2010). The impact of blogging on Hong Kong primary school students' bilingual reading literacy. Australasian Journal of Educational Technology, 26(2), 164-179.

http:/ / www.ascilite.org.au/ajet/ajet26/tse.html

Vonderwell, S. (2003). An examination of asynchronous communication experiences and perspectives of students in an online course: A case study. The Internet and Higher Education, 6, 77-90.

Vygosky, L. (1978). Mind in society: The development of higher psychological processes. Cambridge, MA: Harvard University Press.

Wang, M. J. (2009). Web based projects enhancing English language and generic skills development for Asian hospitality industry students. Australasian Journal of Educational Technology, 25(5), 611-626. http:/ / www.ascilite.org.au/ ajet/ajet25/wang.html

Warschauer, M. (2002). A developmental perspective on technology in language education. TESOL Quarterly, 36(3), 453-475.

Dr Mei-jung Wang, Associate Professor

Department of Applied English

National Kaohsiung University of Hospitality and Tourism

1 Sung-Ho Road, Hsiaokang District, Taiwan 812

Email: sebrinajoy@yahoo.com.tw 